\title{
The Cape Town declaration on access to cardiac surgery in the developing world; is it a true reflection of the needs of SSA?
}

\author{
Robin H. Kinsley", Darshan Reddy" and Charles Yankah" \\ *Lenmed Ethekwini Hospital and Heart Centre, Durban, \\ South Africa \\ "German Heart Centre, Berlin, Germany
}

Address for correspondence:

Dr Robin H. Kinsley

Lenmed Ethekwini Hospital and Heart Centre

I) Riverhorse Drive

Riverhorse Valley

Newlands East

Durban

4037

South Africa

Email:

rkinsley@iafrica.co.za

\section{TOTHE EDITOR}

We read with interest the article by Zille, et al. entitled the Cape Town Declaration on access to cardiac surgery in the developing world.(I) The declaration never mentions the burden of congenital heart disease in Africa. Rather, corrective "lifesaving surgery" for rheumatic heart disease (largely valve replacement) is emphasised. Is this an oversight?

Expensive valve replacement surgery in Africa is a disaster and should not be advocated. Anticoagulation in low- and middleincome countries is hopelessly inadequate; penicillin prophylaxis is variable. By contrast, mitral valve repair is rarely performed ${ }^{(2)}$ because of fly in missions and lack of skills. Even the results of mitral valve repair for rheumatic valvular disease is suboptimal, and is inferior to the results of repair for degenerative mitral valve disease. ${ }^{(3)}$

Zille, et al. estimate that 300 operations per million of the population are required in the developing world. Is this only for rheumatic heart disease or a combination of rheumatic and congenital heart disease? Three hundred thousand children are born annually in Africa with congenital heart disease. Most of these children will require surgical correction, which is extremely efficacious. Many will require further operations - for example, pulmonary valve replacement post Fallots tetralogy. Some patients survive to their teens or even young adulthood without surgery, but subsequently need an operation. So, the number escalates year-on-year.

Sub-Saharan Africa (SSA) is faced with enormous demographic and economic challenges. The incidence of cardiac disease in children approximates that of human immunodeficiency virus infection, ${ }^{(4)}$ but especially non-communicable disease is simply not a government priority. Thus, sadly, only $2 \%$ of paediatric patients in SSA have access to surgical treatment. ${ }^{(5,6)}$

In our view the initial solution would be the establishment of regional cardiac hubs, which, through economics of scale, would reduce costs. Importantly, there should be global standards of training, education and certification, with continued competence. Because of the lack of political priority, some form of privatepublic integration is mandatory.

\section{REFERENCES}

I. SA Heart ${ }^{\circledR}$ 2018;15:190-194

2. Yankah C, Fynn-Thompson F, Antunes M, et al. Cardiac surgery capacity in Sub-Saharan Africa. Quo vadis? Thorac Cardiovasc Surg 20 I4;62(5):393-40 I.

3. Duran CM, Gometza B, Saad E. Valve repair in rheumatic mitral disease: An unsolved problem. J Card Surg 1994 (2 Suppl):282-285.

4. Zille $P$, Yacoub M, Zühlke $L$, et al. Global unmet needs in cardiac surgery. Global Heart 2018; 13:293-303.

5. Yankah C, Fynn-Thompson F, Antunes M, et al. Cardiac surgery capacity in Sub-Saharan Africa. Quo vadis? Thorac Cardiovasc Surg 2014;62(5):393-40I.

6. Metras D, Ouezzin-Coulibaly A, Ouattara K, et al. Open-heart surgery in tropical Africa. Results and peculiar problems of the Ist 300 cases of extracorporeal circulation performed in Abidjan [in French]. Presse Med 1983; | $2(10): 621-624$ 